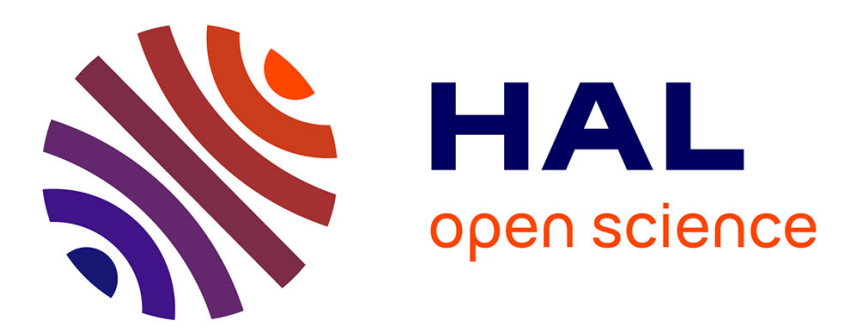

\title{
Up-milling and down-milling wood with different grain orientations - the cutting forces behaviour
}

Giacomo Goli, Marco Fioravanti, Rémy Marchal, Luca Uzielli, Simone Busoni

\section{To cite this version:}

Giacomo Goli, Marco Fioravanti, Rémy Marchal, Luca Uzielli, Simone Busoni. Up-milling and downmilling wood with different grain orientations - the cutting forces behaviour. European Journal of Wood and Wood Products, 2009, 68 (4), pp.385-395. 10.1007/s00107-009-0374-5 . hal-00568252

\section{HAL Id: hal-00568252 \\ https://hal.science/hal-00568252}

Submitted on 23 Feb 2011

HAL is a multi-disciplinary open access archive for the deposit and dissemination of scientific research documents, whether they are published or not. The documents may come from teaching and research institutions in France or abroad, or from public or private research centers.
L'archive ouverte pluridisciplinaire HAL, est destinée au dépôt et à la diffusion de documents scientifiques de niveau recherche, publiés ou non, émanant des établissements d'enseignement et de recherche français ou étrangers, des laboratoires publics ou privés. 


\section{䌼 Springer}

Draft Manuscript for Review

\section{Up and Down-milling wood with different grain orientations - The cutting forces behaviour}

\begin{tabular}{|c|c|}
\hline Journal: & Holz als Roh- und Werkstoff \\
\hline Manuscript ID: & HRW-09-0047.R1 \\
\hline Manuscript Type: & ORIGINALARBEITEN / ORIGINALS \\
\hline $\begin{array}{r}\text { Date Submitted by the } \\
\text { Author: }\end{array}$ & 12-Jun-2009 \\
\hline Complete List of Authors: & $\begin{array}{l}\text { Goli, Giacomo; Università di Firenze, DISTAF } \\
\text { Fioravanti, Marco; Università di Firenze, DISTAF } \\
\text { Marchal, Rémy; ParisTech, Wood Department } \\
\text { Uzielli, Luca; University of Florence, DISTAF } \\
\text { Busoni, Simone; AOU Careggi, Health Physics }\end{array}$ \\
\hline Keywords: & $\begin{array}{l}\text { Douglas Fir, Grain orientation, Up and Down milling, Wood cutting, } \\
\text { Cutting forces, Friction coefficient, Resultant force angle }\end{array}$ \\
\hline
\end{tabular}

\section{S) ScholaroNE \\ Manuscript Central}




\title{
Up and down-milling wood with different grain orientations - the cutting forces behaviour
}

Giacomo Goli ${ }^{1}$, Marco Fioravanti ${ }^{1}$, Rémy Marchal ${ }^{2}$, Luca Uzielli ${ }^{1}$, Simone Busoni $^{3}$

${ }^{1}$ Dipartimento di Scienze e Tecnologie Ambientali Forestali

Università degli Studi di Firenze

Via S. Bonaventura 13 - 50145 Firenze ITALIA

giacomo.goli@unifi.it

${ }^{2}$ LABOMAP

Arts et Metiers ParisTech - Cluny

${ }^{3}$ Health Physics Department - AOU Careggi - Firenze

\begin{abstract}
Peripheral milling of wood with up milling and down milling techniques is very well known from a geometrical point of view. However, in processing anisotropic materials such as wood, these geometrical aspects imply relevant differences when machining. In fact, milling of anisotropic material leads to different cutting geometries when up or down milling and when increasing or decreasing the depth of cut resulting in different grain orientations depending on the adopted process. In this paper, tests performed when processing Douglas Fir with different depths of cut and grain orientations are described. The cutting forces were measured, and the dependence of the cutting forces with respect to the cutting geometry are analysed and discussed.
\end{abstract}

Gleichlauf- und Gegenlauffräsen von Holz bei unterschiedlichem Faserverlauf - Verhalten der Zerspankräfte

\section{Zusammenfassung}

Die geometrischen Aspekte beim Umfangfräsen mittels Gleichlauf- und Gegenlauffräsung sind weitgehend bekannt. Allerdings treten bei der Zerspanung von anisotropen Materialien wie z. B. Holz erhebliche Unterschiede auf. Tatsächlich führt das Fräsen von anisotropen Materialien beim Gleichlauf- und Gegenlauffräsen sowie bei einer Erhöhung oder Reduzierung der Frästiefe zu unterschiedlichen Schneidgeometrien, was in Abhängigkeit des angewandten Verfahrens zu einem unterschiedlichen Winkel zur Faserrichtung führt. Diese Studie berichtet über Ergebnisse von Untersuchungen an Douglasienholz mit unterschiedlichem Faserverlauf, das mit unterschiedlichen Frästiefen bearbeitet wurde. Die Beziehung zwischen den gemessenen Zerspankräften und den Schneidgeometrien wurde untersucht und beschrieben.

\section{Introduction}

It is well known that, when milling a material it can be cut using up-milling or down-milling techniques depending on the direction of the cutting velocity vector 
and the feeding velocity vector. When the two vectors (considered on the tool) have the same direction, the cutting is up-milling (herein after referred to as UM), when the vectors have an opposite direction, the cutting is down-milling (herein after referred to as DM). UM and DM techniques result in geometric differences during the cutting of a chip which is well documented in cutting technology books (Santochi and Giusti 2000). In general, the following is assumed for UM and DM: different shape of the chip, different cutting velocity (albeit often negligible), different wave depth of the surface marks, the beginning of the cut from the thickest (DM) or from the thinnest (UM) part of the chip, different vibro-acoustic behaviour and different relative angle in the cutting path between the grain and the rake face. It has many consequences on other factors such as magnitude and direction of cutting force, tool wear, and evolution of force along the cutting path. The grain orientation is a fundamental factor in order to understand the cutting of wood. Since wood is an anisotropic material it is well known that when stressed in different directions, it behaves differently. The result, when machining with different grain orientations, is a wide range of mechanisms of chip formation that require specific analysis in order to be understood. Essential work has already been carried out regarding cutting geometries, which is well documented in text books (Zompì and Levi 2003, Juan 2000, Santochi and Giusti 2000), and the fundamentals of wood cutting processes (Kivimaa 1950, Franz 1958, McKenzie 1960, 1961, McKenzie and Franz 1964, McKenzie and Cowling 1971a, b, Woodson and Koch 1970, Coch 1972, Mori 1969, 1970, 1971a, b, Piao and Fukui 1984), the basic properties of wood when stressed with different grain orientations (Yoshihara and Ohta 2000), and the surface quality after cutting. Much work concerning the cutting forces behaviour when cutting wood has recently been performed (Eyma et al. 2003, 2004, 2005, Fischer and Gottlöber 2003, Fischer 2004, Palmqvist et al. 2005), as well as processing with different grain orientations using a lathe (Costes et al. 2002). Some work has already been completed in the field of surface quality and grain orientation (Stewart 1969, 1971, Negri and Goli 2000, Goli et al. 2002, 2003, 2004a, b), and certain scholarly articles analyse some of the above mentioned factors together (Cyra and Tanaka 2000). This paper follows the paper "Up-milling and down-milling wood with different grain orientations - theoretical background and general appearance of the chips" - (Goli et al. 2009) and aims at giving confirmation by analysis of the cutting forces, the theoretical background already presented. The theoretical background, already discussed in the above-mentioned paper, will not be discussed in this work.

\section{Materials and Methods}

In a peripheral milling operation, Douglas fir was up- and down-milled using a straight blade router. The specimen was machined along and across the grain, and with and against the grain, varying the grain orientation in steps of $10^{\circ}$. Using the notation proposed by McKenzie $(\Omega-\Phi)$ in order to describe the grain orientation, the angle $\Omega$ was kept constant at $90^{\circ}$ while $\Phi$ was varied. When $\Phi=0^{\circ}$ processing is along the grain, tilting the grain leads to processing with $(0<\Phi<90)$ or against $(0>\Phi>-90)$ the grain. Finally, because the cutting geometry at $90^{\circ}$ is the same at $-90^{\circ}$, these values of $\Phi$ lead to processing across the grain. Tangential specimens were processed on their radial face in order to minimise the effects of the interactions between early and late wood. Specimens were cut using the same straight grain oriented board and they were cut as close as possible to each other 
in order to minimise the wood variability. The samples used are described in Table 1 and the experimental set-up in Table 2.

Table 1: Description of the specimens used in the tests and relative abbreviations.

Table 2: Experimental set-up and relative abbreviations.

In the tests, the cutting forces were measured by means of a tri-axial piezoelectric dynamometric platform which is able to offer good reliability and stiffness. The charge amplifiers were set to "long" mode. The platform was firmly screwed on a steel plate, rectified on both sides, and fixed on the machine table by a conventional vacuum system. The specimen was firmly screwed directly above the dynamometric platform and the specimen was positioned in such a way to assure only peripheral contact with the cutting tool (the top of the tool is not working). The machine was tested in order to verify the repeatability of the cutting head positioning which was measured in a range of $\pm 0,05 \mathrm{~mm}$. The reference surface was obtained by cutting 10 times with a depth of cut of 0.05 $\mathrm{mm}$. Even, if very close to the repeatability of the machine, after 10 cuts of 0.05 $\mathrm{mm}$ the absolute error can still be considered equal to $0.05 \mathrm{~mm}$ allowing to obtain very thin chips and a process very close to sanding rather than routing and a very clear reference surface. In fact. already processing at $0.1 \mathrm{~mm} d o c$ results in surface defects propagating under the surface. The final cut $(0.5 \mathrm{~mm}$ or $1.5 \mathrm{~mm}$ doc) was made during the same working cycle in order to reduce the positioning error as much as possible.

The acquired forces were the cutting force $(F c)$ and the normal force $(F n)$ as reported in Figure 1, the lateral force was ignored because it is not considered relevant.

The cutting force $(F c)$ is considered positive in the direction of the feeding speed and the normal force $(F n)$ in the direction into the specimen. The cutting force signals were digitized by means of a computer board with a sampling frequency of $10 \mathrm{kHz}$.

Figure 1: a) Specimen hanging on the dynamometric platform during a cut and b) cutting forces orientation. $\mathrm{Fc}=$ cutting force, $\mathrm{Fn}=$ normal force, $\mathrm{R}=$ resultant force, $-\mathrm{R}=$ reaction to the resultant force, $R^{\circ}=$ resultant force angle, $S=$ force parallel to the rake face, $N=$ force perpendicular to the rake face, $V c=$ cutting velocity, $\gamma=$ rake angle, $\beta=$ wedge angle.

\section{Cutting forces analysis}

Measurement of the cutting forces during conventional machining operation is very difficult because of interferences due to system vibrations. The cutting head revolution frequency was $231 \mathrm{~Hz}$ that means $0.0043 \mathrm{~s}$ per revolution and when considering two cutting edges the frequency must be doubled and the time halved. The acquired data were observed by a normal time-intensity graph and an autocorrelation function was applied. Some examples of the collected data and the 
performed analysis follow here. For the time intensity analysis, the time in seconds is shown on the $\mathrm{x}$-axis, while the force is shown on the $\mathrm{y}$-axis directly (in $\mathrm{N} / \mathrm{mm}$ of blade width) as from the output of the load cell. For the autocorrelation function the time is shown on the $\mathrm{x}$-axis and an index going from 1 to -1 (1: perfectly correlated, -1 : anti-correlated) on the y-axis.

In Figure 2, the rough signal during idle processing and DM of a specimen $20^{\circ}$ with the grain is shown. Processing idle (Figure 2a) the noise can be considered as negligible being lower than $0.05 \mathrm{~N} \mathrm{~mm}^{-1}$. While when processing a specimen (Figure $2 b$ ), the effect of the forced vibration consequent to the blade impact on the specimen is clear. The forces reported in Figure $2 b$ are not easy to interpret. Anyhow, the single impacts are visible and producing in this case regular forces between 2 and $2.3 \mathrm{~N} \mathrm{~mm}^{-1}$.

Figure 2: Unfiltered signal processing idle (a) and machining a specimen $20^{\circ}$ with the grain, with $0.5 \mathrm{~mm}$ doc and with down-milling technique (b). The force is in $\mathrm{N} / \mathrm{mm}$ of blade length.

Unfiltered peak forces vs. grain orientation plots were analysed and showed a very high standard deviation. In order to reduce vibration noise, data were processed using a low-pass filter. Even though it is well known that filtering might alter the absolute values of the cutting forces, the values of the filtered force could be satisfactory used for comparison between different processes. Several cut-off frequencies $(500 \mathrm{~Hz}, 1000 \mathrm{~Hz}$ and $1500 \mathrm{~Hz}$ ) were tested and finally a 500 $\mathrm{Hz} 4^{\text {th }}$ order Butterworth Low-pass filter was chosen.

The filter was set at a frequency slightly higher than the cutting frequency (cutting frequency $462 \mathrm{~Hz}$ ) and five times lower than the natural frequency of the piezoelectric dynamometric platform (declared by the manufacturer being 2.3 $\mathrm{kHz})$.

In Figure $3 a$, the filtered signal when DM of a specimen $20^{\circ}$ with the grain 0.5 $\mathrm{mm} d o c$ is shown (the unfiltered signal is shown in Figure $2 b$ ). As can be seen the impacts become much more visible and the signal much clearer. This higher clearness is paid for by a reduction of the signal that for $F c$ passes from a range between 2 and $2.3 \mathrm{~N} \mathrm{~mm}^{-1}$ if unfiltered (see Figure $2 b$ ) to a range between 0.4 and $0.5 \mathrm{~N} \mathrm{~mm}^{-1}$, if filtered (see Figure $3 a$ ).

Figure 3: $500 \mathrm{~Hz}$ low-pass filtered signal when machining of a specimen $20^{\circ}$ (a) and $80^{\circ}$ (b) with the grain, with $0.5 \mathrm{~mm} d o c$ and with down-milling technique. The force is in $\mathrm{N} / \mathrm{mm}$ of blade length.

If the filtered signal acquired when processing $20^{\circ}$ with the grain (see Figure $3 a$ ) is compared with that of $80^{\circ}$ with the grain (Figure $3 \mathrm{~b}$ ), an increase of magnitude can be observed even if the signal shape remains almost the same. By analysing the signals during machining, the periodicity clearly appears to be the same when processing with different grain orientations $(0.0043 \mathrm{~s})$ as can be observed in Figures $2 b, 3 a, 3 b$ and as highlighted by the autocorrelation function in Figure $4 b$. The periodicity corresponds to one revolution of the tool meaning that in the cutting process, even having two tools involved, only one tool is cutting and the other is not working at all or in some cases rubbing. Because the second blade 
Figure 4: Autocorrelation function of the (a) unfiltered and (b) filtered signals while machining a specimen $20^{\circ}$ with the grain with $0.5 \mathrm{~mm}$ doc and with down-milling technique.

In order to study the general trend of the forces a software code (based on IDL platform) dedicated to automatic peak force selection was written. The peak extractor was programmed to search only the peaks situated in a time window covering the cutting period comb at a given frequency and exceeding a given threshold. While no coherent data were obtained by running the application on the unfiltered data because of the very high noise, after filtering at $1000 \mathrm{~Hz}$ and, in particular at $500 \mathrm{~Hz}$, the general trend of the forces became visible. The general trend of the signal after filtering at $500 \mathrm{~Hz}$ is reported in Figure $5 a$ and $b$. The $50^{\circ}$ datum up- and down-milling with a depth of cut of $0.5 \mathrm{~mm}$ was omitted because it was not coherent in magnitude with the others.

Figure 5: The forces peaks processing Douglas fir with Up- and Down-milling techniques computing with an automatic IDL script on $500 \mathrm{~Hz}$ filtered signals.

The force data are difficult to compare with the ones by other authors because of the differences in the cutting process, cutting geometries, different species and moisture content. Anyhow the force data were roughly compared with the cutting forces measured by Kivimaa (1950) and Eyma et al. (2003) using species with the same density. The result was that the filtered peaks in this study had a very low magnitude, while the unfiltered data could be considered as more in line with the expected forces according to bibliographic sources. When processing the unfiltered signals with the same IDL peak extractor as used for the filtered signals the cutting forces can not be derived easily because of the relevant scattering of the values. Anyhow, just to give general scale factors the unfiltered $/ 500 \mathrm{~Hz}$ filtered data ratio is around 6 (SD 2) for Fc and around 3.5 (SD 1) for Fn making the values much closer to those obtained by the cited authors. The trends obtained are as expected from bibliographic sources and then the signals were considered acceptable for further analysis. In order to overcome some limits of the IDL 
program that was running on the entire cutting length, specific parts of the acquired data were selected because they were considered as steady state cutting phases. The signal was filtered and the peaks following an impact measured. A number of 15 measurements were averaged to determine the value of the average cutting forces and the coefficient of variation of the collected data is reported in Table 3.

Table 3: Coefficient of variation of the measured cutting forces for $0.5 \mathrm{~mm}$ doc (wg: with the grain, ag: against the grain).

\section{Cutting force and normal force}

In the following part the behaviour of the cutting forces as a function of the grain orientation is presented, analysed and discussed. A B-Spline fit was applied and the measurements were made directly on the B-Spline. In Figure 6 the normalised filtered cutting forces $\mathrm{UM}$ and DM with $0.5 \mathrm{~mm} d o c$ are shown and different trends can be observed for $F c$ and $F n$. $F c$ vs. grain orientation plots show very similar shapes when DM and UM but a consistent horizontal shift of the minimums. This shift was measured $28^{\circ}$ between $F_{c} \mathrm{UM}$ and $F c$ DM and $14^{\circ}$ for Fn UM and Fn DM.

Figure 6: Cutting forces $(\mathrm{Fc})$ and normal forces (Fn) when up and down milling of Douglas fir with $0.5 \mathrm{~mm}$ of depth of cut with different grain orientations.

A very similar behaviour (see Figure 7) can be observed for $1.5 \mathrm{~mm}$ of $d o c$ where the shift between the minima of $F_{c} \mathrm{UM}$ and $F_{c} \mathrm{DM}$ is $34^{\circ}$ while for $F n$ it is $21^{\circ}$.

Figure 7: Cutting forces $(\mathrm{Fc})$ and normal forces (Fn) when up and down milling of Douglas fir with $1.5 \mathrm{~mm}$ of depth of cut with different grain orientations.

The observed shifts seem to be coherent with the theoretical background presented in the paper by Goli et al. (2009) and a shift in the cutting forces can also be observed in the chip types. In order to improve this aspect the resultant forces $(R)$ were analysed.

\section{Resultant force magnitude}

The resultant force magnitude $(R)$ depends on several factors. Anyhow, considering that a given material with given moisture content and with given cutting and feeding speeds was machined, it can be said that $R$ mainly depends on two factors:

- the depth of cut

- the relative grain orientation (Goli et al. 2009).

The effects of these two factors on the resultant force magnitude cannot be disentangled easily. Nevertheless in the plots a vertical effect (the plots magnitude 
Figure 8: Resultant force magnitude when up- and down milling Douglas fir with 0.5 and $1.5 \mathrm{~mm}$ of depth of cut.

The measured and expected shifts are as reported in Table 4 but the main shifts are:

- $5^{\circ}$ between $1.5 \mathrm{~mm}$ doc $\mathrm{DM}$ and $0.5 \mathrm{~mm}$ doc DM (13 expected)

- $22^{\circ}$ between $0.5 \mathrm{~mm}$ doc $\mathrm{DM}$ and $0.5 \mathrm{~mm}$ doc UM (22 expected)

- $5^{\circ}$ between $0.5 \mathrm{~mm}$ doc $\mathrm{UM}$ and $1.5 \mathrm{~mm}$ doc $\mathrm{UM}$ (13 expected).

Table 4: Measured and expected shifts between the resultant forces when UM and DM with 0.5 and $1.5 \mathrm{~mm}$ of depth of cut. The main shifts are in bold.

\section{Resultant force angle}

In Figure 9, the resultant force angle $\left(R^{\circ}\right)$ vs. the grain orientations is plotted. This angle, being the angle between the working plane and the resultant force, expresses how the resultant force is directed inside the specimen. The higher the angle, the more inside the specimen the force is directed.

Figure 9: Resultant force angle (angle between the normal force and the resultant force) when upand down-milling Douglas fir with 0.5 and $1.5 \mathrm{~mm}$ of depth of cut.

The radial shift of the graphs clearly shows how the force goes more and more inside the specimen when passing from $1.5 \mathrm{~mm}$ doc UM to $1.5 \mathrm{~mm}$ doc DM. In particular, the following average increases of resultant force angle can be measured:

- $7.1^{\circ}$ between $1.5 \mathrm{~mm}$ doc UM and $0.5 \mathrm{~mm}$ doc UM (SD 3.5)

- $11.6^{\circ}$ between $0.5 \mathrm{~mm}$ doc UM and $0.5 \mathrm{~mm}$ doc DM (SD 5.5)

- $\quad-2^{\circ}$ between $0,5 \mathrm{~mm}$ doc $\mathrm{DM}$ and 1,5 $\mathrm{mm}$ doc DM (SD 3,5) 
The resultant force vectors UM and DM with different $d o c$ and with different grain orientations are reported in Figure 10.

Figure 10: Resultant force magnitude and direction when Up-milling and Down-milling with different grain orientations and depths of cut. In the centre of the tool the grain orientation is indicated in degrees.

It is clear how DM with 0.5 and $1.5 \mathrm{~mm}$ doc presents different magnitudes in the forces but very similar force directions. This is probably because of the penetration mechanisms when the cutting starts.

\section{Forces parallel and perpendicular to the rake face, and $S$ and $N$ ratio}

The decomposition of the $R$ in the $S$ (parallel to the rake face) and $N$ (perpendicular to the rake face) components does not lead to more different results than those already observed for $F c$ and $F n$. Anyway, $S$ and $N$ (computed as in [7] and [8] where $\gamma$ is the rake angle) allow for the calculation of the coefficient of friction $(\mu)$ :.

$$
\begin{gathered}
\mathrm{S}=\mathrm{Fc} \sin \gamma+\text { Fn } \cos \gamma[7] \\
\mathrm{N}=\mathrm{Fc} \cos \gamma-\text { Fn } \sin \gamma[8] \\
\mu=\mathrm{S} / \mathrm{N}[9]
\end{gathered}
$$

The $\mu$ coefficient of the fragmented chip, which in the case of flowing chip can be regarded as a coefficient of friction, is difficult to be regarded like in the Amontons/Coulomb theory. In fact, during the cutting of wood with different grain orientations, the chip is completely destroyed in many cases and does not slide on the rake face. Anyhow, the behaviour of this coefficient with respect to $\mathrm{UM}$ and DM with different grain orientation and $d o c$ can give interesting information on the process. Due to this statement it is preferred to name this parameter $S$ and $N$ ratio $(\mu)$ instead of coefficient of friction. Figure 11 shows $\mu$ plotted vs. the grain orientation. The $S$ and $N$ ratio goes from a minimal value of about 0.4 to a maximal value of about 1.5 increasing progressively from UM with a depth of cut of $1.5 \mathrm{~mm}$, where the values are minimal, to DM with a depth of cut of $1.5 \mathrm{~mm}$, where the maximal values are obtained passing respectively from 0,5 $\mathrm{mm}$ doc UM and 0,5 $\mathrm{mm} \mathrm{DM}$. The shifts observed in the cutting forces can be observed either for the $S$ and $N$ ratio and higher values of this coefficient seem to be when machining between $10^{\circ}$ and $30^{\circ}$ with the grain. This is a fundamental point because it should be considered that $20^{\circ}$ increase or decrease of the work angle is the condition where the rake face and the grain orientation are parallel.

Figure 11: $\mathrm{S}$ and $\mathrm{N}$ ratio (coefficient of friction $\mu$ ) vs. grain orientation.

As for $R^{\circ}$ even for the $S$ and $N$ ratio DM with 0.5 and $1.5 \mathrm{~mm}$ doc do not lead to very different behaviour. Anyhow for these two processes, the ratio seems to be very close for grain values higher than -10 (processing with the grain) and 
becomes different for values lower than -10 (processing then against the grain). This could support the hypothesis of a similar penetration of the blade during the cutting start.

\section{Conclusion}

Cutting of wood with different grain orientations offers a very wide range of phenomena. The geometrical basis was discussed and some relevant connections were found between grain orientation, depth of cut and cutting forces. A method to measure, analyse and compare the cutting forces was developed. The experimental results offer a complete support to the theoretical background finding a horizontal shift in the cutting forces plotted vs. the grain orientation for the different cutting processes. The evolution of the resultant force was explained by the relative grain orientation, and the resultant force angle and the "friction coefficient" were discussed adding a new point of view for the cutting of wood with turning tool, different grain orientations and depths of cut.

ACKNOWLEDGMENTS: We would like to acknowledge the group UGV (Usinage Grande Vitesse) of the ENSAM Cluny for the help with the CNC router and the dynamometric platform that made this work possible.

\section{References}

Coch P (1972) Utilization of the southern pines Vol.2. U.S. Department of Agriculture-Forest Service

Costes JP, Lim Ko P, Ji T, Decés-Petit C, Altintas Y (2002) Orthogonal cutting mechanics of maple: modelling a solid wood-cutting process. J. of Wood Sci. 50-1: 28-34

Cyra G, Tanaka C (2000) The effects of wood fiber directions on acoustic emission in routing. Wood Sci. Technol. 34: 237-252

Eyma F, Meausoone PJ, Martin P (2003) Two original methods to calculate precisely cutting forces involved during routing (90-0) Proceedings of the 16th International Wood Machining Seminar

Eyma F, Méausoone PJ, Martin P (2004) Study of the properties of thirteen tropical wood species to improve the prediction of cutting forces in mode B. Ann. For. Sci. 61 pag. 55-64.

Eyma F, Méausoone PJ, Larricq P, Marchal R (2005) Utilization of a dynamometric pendulum to estimate cutting forces involved during routing. Comparison with actual calculated values. Ann. For. Sci. 62: 441-447

Fischer R, Gottlöber C (2003) Basics in the optimisation of wood cutting in the example of peripheral milling. Proceedings of the 16th International Wood Machining Seminar Fischer R (2004) Micro processes at cutting edge - Some basics on machining wood. Proceedings of the 2nd International Symposium on Wood Machining

Franz NC (1958) An analysis of the wood cutting process. PhD. Thesis University Michigan Ann Arbor

Goli G, Bleron L, Marchal R, Uzielli L, Negri M (2002) Surfaces formation and quality, in moulding wood at various grain angles. Initial results with Douglas fir and oak. Proceedings of the conference Wood Structure and Properties

Goli G, Marchal R, Uzielli L, Negri M, (2003) Measuring cutting forces in routing wood at various grain angles. Study and comparison between up and down-milling techniques, processing Douglas fir and oak. Proceedings of the 16th International Wood Machining Seminar Goli G, Marchal R, Uzielli L, (2004a) Classification of wood surface defects according to their mechanical formation during machining. Proceedings of the 2nd International Symposium on Wood Machining Goli G, Uzielli L (2004b) Mechanisms of wood surface formation and resulting final condition after planing. Proceedings of the 2nd International Symposium on Wood Machining Goli G, Fioravanti M, Sodini N, Jiangang Z, Uzielli L (2005) Wood Processing: a contribute to the interpretation of surface origin according to grain orientation. Proceedings of the 17 th International Wood Machining Seminar 
Goli G, Fioravanti M, Marchal R, Uzielli L (2009): Up-milling and down-milling wood with different grain orientations - theoretical background and general appearance of the chips. Eur. J. Wood. Prod. 67(3); 257-263

Kivimaa E (1950) Cutting force in woodworking. State institute for Technical Research, VTT Publication No. 18

Koch P. (1972): Utilization of the southern pines Vol. II, U.S. Department of Agriculture-Forest Service

Juan J (2000) Comment bien usiner le bois. CTBA

McKenzie WM (1960) Fundamental aspects of the wood cutting process. Forest Prod. J.10: 447456

McKenzie WM (1961) Fundamental aspects of the wood cutting process. PhD. Thesis University Michigan Ann Arbor

McKenzie WM, Franz NC (1964) Inclined or oblique wood cutting. Forest Prod. J.14: 555-566 McKenzie WM, Cowling RL (1971a) A factorial experiment in transverse plane cutting of wood Part I. Cutting force and edge wear. Wood Science 3(4): 204-213

McKenzie WM, Cowling RL (1971b) A factorial experiment in transverse plane (90/90) cutting of wood - Part II. Chip formation. Wood Science 4(1): 55-61

Mori M (1969) An analysis of cutting work in peripherial milling of wood. I On the work done by a knife in up-milling parallel to wood grain. Mokuzai Gakkaishi 15: 93-98

Mori M (1970) An analysis of cutting work in peripherial milling of wood. II The cutting force, power and energy requirements in up-milling parallel to wood grain. Mokuza Gakkaischi 16: 1-9 Mori M (1971a) An analysis of cutting work in peripherial milling of wood. III Variation of cutting force in inside cutting of wood with router-bit. Mokuzai Gakkaishi 17: 437-442 Mori M (1971b) An analysis of cutting work in peripherial milling of wood. IV The power requirements in inside cutting of wood with router-bit. Mokuzai Gakkaishi 17: 443-448 Negri M, Goli G (2000) Qualità delle superfici lavorate del legno di Abete rosso e di Douglasia valutata con una opportuna classificazione visuale. Legno Cellulosa Carta 6(1): 10/21

Palmqvist J, Lenner M, Gustafsson SI (2005) Cutting forces when up-milling in beech. Wood Sci. Technol 39: 674-684

Piao SY, Fukui H (1984) Specific cutting-force in the machining of wood I. Dependence on rake and clearance angles and effect of chip thickness. Mokuzai Gakkaishi 30: 359-367

Santochi M, Giusti F (2000) Tecnologia meccanica e studi di fabbricazione. Casa Editrice Ambrosiana

Stewart HA (1971) Chip formation when orthogonally cutting wood against the grain. Wood Sci. Tecnol. 3(4): 193-203

Stewart HA (1969) Effect of cutting direction with respect to grain angle on the quality of machined surface, tool force components, and cutting friction coefficient. Forest Product Journal Vol. 19(3): 43-46

Woodson GE, Koch P (1970) Tool forces and chip formation in orthogonal cutting of loblolly pine. Department of Agriculture-Forest Service research paper SO-52

Yoshihara H, Ohta M (2000) Estimation of the shear strength of wood by uniaxial-tension tests of off-axis specimens. J. Wood Sci 46: 159-163

Zompì A, Levi R (2003): Tecnologia Meccanica. Lavorazioni ad asportazione di truciolo, UTET Libreria. 
Table 1: Description of the specimens used in the tests and relative abbreviations.

\begin{tabular}{l|l}
\hline Species: & Douglas fir (Pseudotsuga \\
& Menziesii Fr. Var. Menziesii) \\
Moisture content $(\mathrm{mc}):$ & $13 \%$ \\
Average specific gravity $\left(\rho_{12}\right):$ & $0,43 \mathrm{~g} / \mathrm{cm} 3$ \\
Depths of cut $($ doc $):$ & $0,5-1,5 \mathrm{~mm}$ \\
Cutting length $(\mathrm{l}):$ & $80 \mathrm{~mm}$ \\
Cutting height $(\mathrm{h}):$ & $30 \mathrm{~mm}$ \\
\hline
\end{tabular}


Table 2: Experimental set-up and relative abbreviations.

\begin{tabular}{l|l}
\hline Milling machine type: & 3 axes CNC router \\
Milling machine model: & SCM Record 1 \\
Rake angle $(\gamma):$ & $20^{\circ}$ \\
Clearance angle $(\alpha):$ & $15^{\circ}$ \\
Inserts on the cutting head (z): & 2 \\
Inserts material: & tungsten carbide screwed \\
& inserts $(\mathrm{WC})$ \\
Cutting technology: & up-milling (UM) and down \\
Feeding speed $(\mathrm{F}):$ & milling (DM) \\
Cutting speed $(\mathrm{Vc}):$ & $5 \mathrm{~m} / \mathrm{min}$ \\
Tool revolutions: $(\mathrm{S}):$ & $29 \mathrm{~m} / \mathrm{s}$ \\
Cutting head diameter $(\mathrm{D}):$ & $13867 \mathrm{rev} / \mathrm{min}$ \\
Cutting head ray $(\mathrm{R}):$ & $40 \mathrm{~mm}$ \\
\hline
\end{tabular}


Table 3: Coefficient of variation of the measured cutting forces for $0.5 \mathrm{~mm}$ doc (wg: with the grain, ag: against the grain).

\begin{tabular}{lllllllllll}
\hline Grain orientation & $0^{\circ}$ & $10^{\circ}$ & $20^{\circ}$ & $30^{\circ}$ & $40^{\circ}$ & $50^{\circ}$ & $60^{\circ}$ & $70^{\circ}$ & $80^{\circ}$ & $90^{\circ}$ \\
Fn UM wg & 0,07 & 0,06 & 0,05 & 0,13 & 0,06 & 0,11 & 0,05 & 0,03 & 0,06 & 0,09 \\
Fc UM ag & 0,04 & 0,05 & 0,07 & 0,05 & 0,04 & 0,04 & 0,03 & 0,05 & 0,03 & 0,04 \\
Fn DM wg & 0,04 & 0,08 & 0,03 & 0,10 & 0,04 & 0,07 & 0,11 & 0,01 & 0,02 & 0,04 \\
Fc DM ag & 0,04 & 0,04 & 0,07 & 0,04 & 0,04 & 0,03 & 0,04 & 0,07 & 0,08 & 0,02 \\
\hline
\end{tabular}


Table 4: Measured and expected shifts between the resultant forces UM and DM with 0.5 and 1.5 $\mathrm{mm}$ of depth of cut. The main shifts are in bold.

\begin{tabular}{l|c|c|c|c|c|c|c|c}
\hline & \multicolumn{2}{|c}{$1,5 \mathrm{~mm}$ doc DM } & \multicolumn{2}{c}{$0,5 \mathrm{~mm}$ doc DM } & \multicolumn{2}{c}{$0,5 \mathrm{~mm}$ doc UM } & \multicolumn{2}{c}{$1,5 \mathrm{~mm}$ doc UM } \\
& Meas. & Expec. & Meas. & Expec. & Meas. & Expec. & Meas. & Expec. \\
\hline $1,5 \mathrm{~mm}$ doc DM & $/$ & $/$ & $5^{\circ}$ & $13^{\circ}$ & $27^{\circ}$ & $35^{\circ}$ & $32^{\circ}$ & $48^{\circ}$ \\
\cline { 2 - 9 } $0,5 \mathrm{~mm}$ doc DM & $\mathbf{5}^{\circ}$ & $\mathbf{1 3}^{\circ}$ & $/$ & $/$ & $22^{\circ}$ & $22^{\circ}$ & $27^{\circ}$ & $35^{\circ}$ \\
\hline $0,5 \mathrm{~mm}$ doc UM & $27^{\circ}$ & $22^{\circ}$ & $\mathbf{2 2}^{\circ}$ & $\mathbf{2 2}^{\circ}$ & $/$ & $/$ & $5^{\circ}$ & $13^{\circ}$ \\
$1,5 \mathrm{~mm}$ doc UM & $32^{\circ}$ & $48^{\circ}$ & $27^{\circ}$ & $35^{\circ}$ & $\mathbf{5}^{\circ}$ & $\mathbf{1 3}^{\circ}$ & $/$ & $/$ \\
\hline
\end{tabular}

Tabelle 1

Beschreibung der Versuchsparameter und jeweilige Abkürzungen

Tabelle 2

Versuchsbedingungen und jeweilige Abkürzungen

Tabelle 3

Variationskoeffizienten der gemessenen Zerspankräfte bei einer Frästiefe von 0,5 mm (wg: Gleichlauf, ag: Gegenlauf)

Tabelle 4

Gemessene und erwartete Verschiebung der resultierenden Kräfte beim

Gleichlauf- und Gegenlauffräsen mit einer Frästiefe von $0,5 \mathrm{~mm}$ und 1,5 mm. Die wichtigsten Verschiebungen sind fettgedruckt.

Abb. 1

a) Beim Zerspanen hängt der Prüfkörper an einer dynamometrischen Plattform, b) Richtung der Zerspankräfte

$\mathrm{Fc}=$ Zerspankraft, $\mathrm{Fn}=$ Normalkraft, $\mathrm{R}=$ resultierende Kraft, $\mathrm{R}=$ Gegenkraft zur resultierenden $\mathrm{Kraft}, \mathrm{R}^{\circ}=$ resultierender Kraftwinkel, $\mathrm{S}=$ Kraft parallel zum Fräswerkzeug, $\mathrm{N}=$ Kraft rechtwinklig zum Fräswerkzeug, $\mathrm{Vc}=$ Zerspangeschwindigkeit, $\gamma=$ Spanwinkel, $\beta=$ Keilwinkel

Abb. 2

Ungefiltertes Signal a) beim Leerlauf und b) bei der Bearbeitung eines Prüfkörpers mit $20^{\circ}$ Faserabweichung im Gegenlauf mit einer Frästiefe von 0,5 $\mathrm{mm}$. Die Kraft ist in N/mm der Blattlänge angegeben.

Abb. 3

$500 \mathrm{~Hz}$ Tiefpass gefiltertes Signal bei der Zerspanung eines Prüfkörpers bei einer Faserabweichung von a) $20^{\circ}$ und b) $80^{\circ}$ im Gegenlauf mit einer Frästiefe von 0,5 $\mathrm{mm}$. Die Kraft ist in $\mathrm{N} / \mathrm{mm}$ der Blattlänge angegeben.

Abb. 4

Autokorrelationsfunktion der a) ungefilterten und b) gefilterten Signale bei der Zerspanung eines Prüfkörpers bei $20^{\circ}$ Faserabweichung im Gegenlauf.

Abb. 5

Höchstkräfte beim Zerspanen von Douglasienholz im Gleichlauf und Gegenlauf, die mit einem Programm auf IDL Basis aus mit $500 \mathrm{~Hz}$ gefilterten Signalen berechnet wurden. 
Abb. 6

Zerspankräfte $(\mathrm{Fc})$ und Normalkräfte $(\mathrm{Fn})$ beim Gleichlauf- und Gegenlauffräsen von Douglasienholz mit einer Frästiefe von $0,5 \mathrm{~mm}$ bei unterschiedlichem Faserverlauf.

Abb. 7

Zerspankräfte $(\mathrm{Fc})$ und Normalkräfte $(\mathrm{Fn})$ beim Gleichlauf- und Gegenlauffräsen von Douglasienholz mit einer Frästiefe von $0,5 \mathrm{~mm}$ bei unterschiedlichem Faserverlauf.

Abb. 8

Resultierende Kraft beim Gleichlauf- und Gegenlauffräsen von Douglasienholz mit einer Frästiefe von 0,5 mm und 1,5 mm in Abhängigkeit des Faserverlaufs.

Abb. 9

Resultierender Kraftwinkel (Winkel zwischen der Normalkraft und der resultierenden Kraft) beim Gleichlauf- und Gegenlauffräsen von Douglasienholz mit einer Frästiefe von 0,5 mm und 1,5 mm in Abhängigkeit des Faserverlaufs.

\begin{abstract}
Abb. 10
Resultierende Kraft, Richtung beim Gleichlauf- und Gegenlauffräsen von Douglasienholz bei unterschiedlichem Faserverlauf und Frästiefe. In der Mitte des Werkzeugs ist die Faserrichtung in Grad angegeben.
\end{abstract}

Abb. 11

S und N Verhältnis in Abhängigkeit des Faserverlaufs 

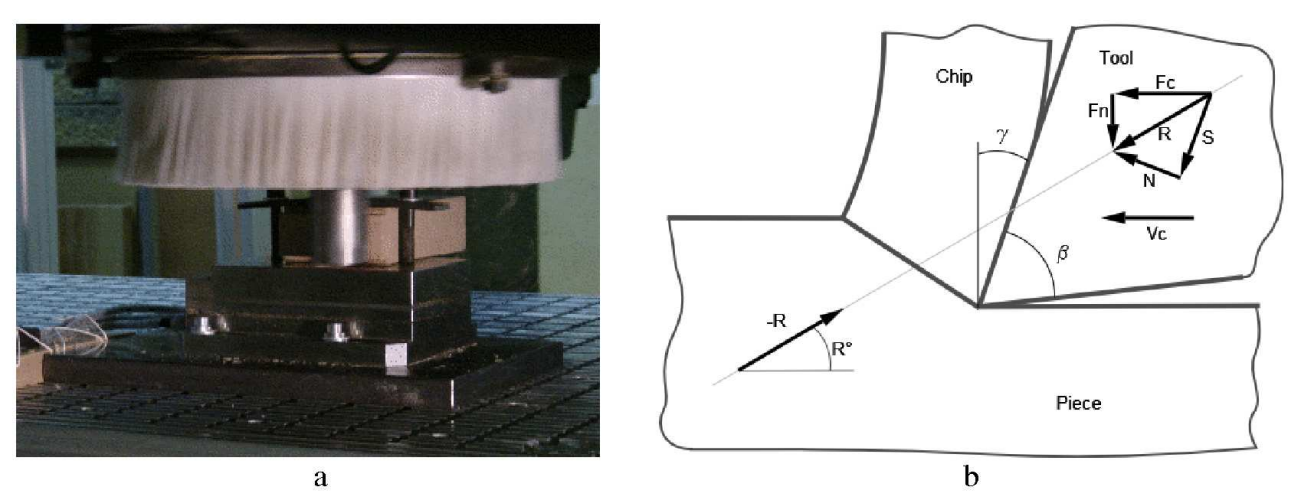

Figure 1: The specimen hanging on the dynamometric platform during a cut (a) and the cutting forces orientation (b). $F c=$ cutting force, $F n=$ normal force, $R=$ resultant force, $-\mathrm{R}=$ reaction to the resultant force, $\mathrm{R}^{\circ}=$ resultant force angle, $\mathrm{S}=$ force parallel to the rake face, $\mathrm{N}=$ force perpendicular to the rake face, $\mathrm{Vc}=$ cutting velocity, $\mathrm{Y}=$ reke angle, $\beta=$ wedge angle. $143 \times 55 \mathrm{~mm}(300 \times 300 \mathrm{DPI})$ 


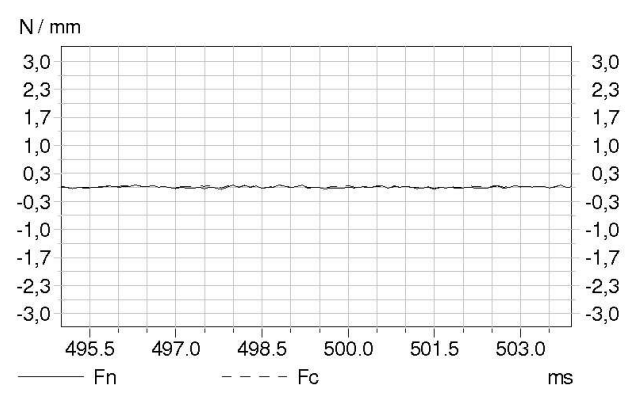

a

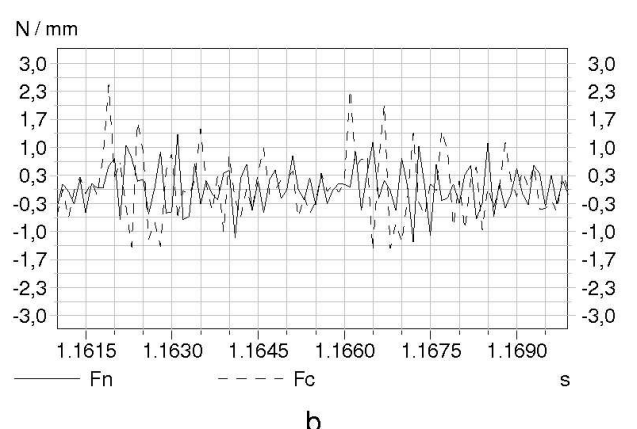

b

Figure 2: Unfiltered signal processing idle (a) and machining a specimen $20^{\circ}$ with the grain, with $0,5 \mathrm{~mm}$ doc and with down-milling technique (b). The force is in $\mathrm{N} / \mathrm{mm}$ of blade length. $138 \times 47 \mathrm{~mm}(300 \times 300 \mathrm{DPI})$ 


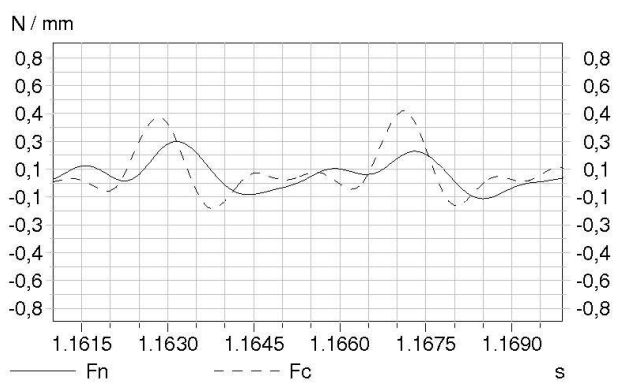

a

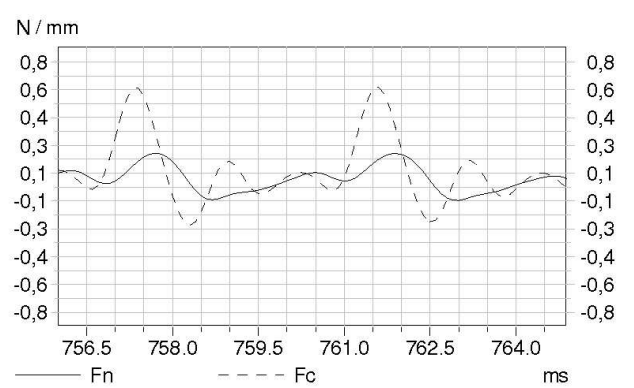

b

Figure 3: $500 \mathrm{~Hz}$ low-pass filtered signal machining a specimen $20^{\circ}$ (a) and $80^{\circ}$ (b) with the grain, with $0,5 \mathrm{~mm}$ doc and with down-milling technique. The force is in $\mathrm{N} / \mathrm{mm}$ of blade length. $139 \times 47 \mathrm{~mm}(300 \times 300 \mathrm{DPI})$ 
Figure 4: Autocorrelation function of the unfiltered (a) and filtered (b) signals while machining a specimen $20^{\circ}$ with the grain with $0,5 \mathrm{~mm}$ doc and with down-milling technique. $139 \times 48 \mathrm{~mm}(300 \times 300 \mathrm{DPI})$ 


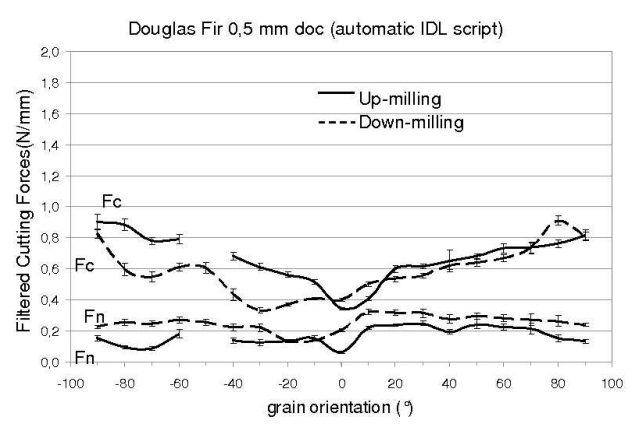

a

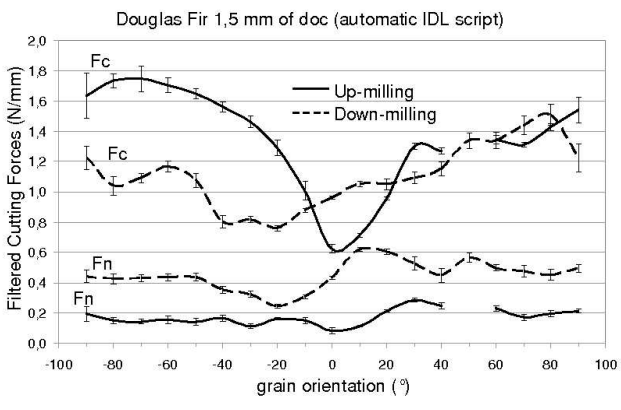

b

Figure 5: The forces peaks processing Douglas Fir with Up- and Down-milling techniques computing with an automatic IDL script on $500 \mathrm{~Hz}$ filtered signals. $141 \times 50 \mathrm{~mm}(300 \times 300 \mathrm{DPI})$ 
Fc and Fn for Douglas Fir processed with $0,5 \mathrm{~mm}$ of depth of cut

Figure 6: Cutting forces $(\mathrm{Fc})$ and normal forces $(\mathrm{Fn})$ up and down milling Douglas Fir with $0,5 \mathrm{~mm}$ of depth of cut with different grain orientations.

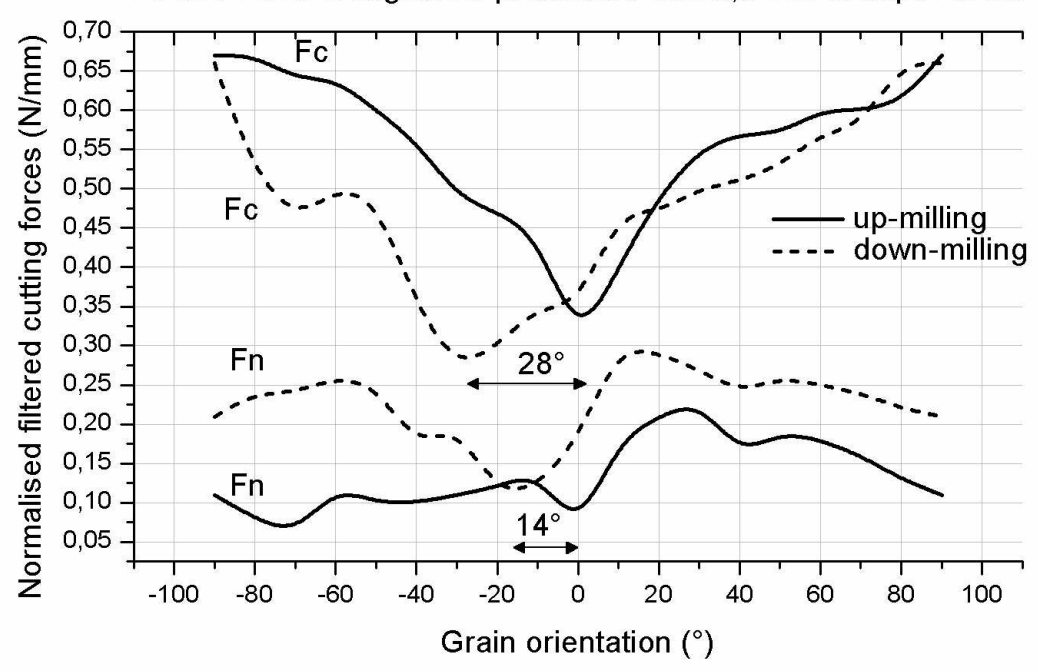
$287 \times 162 \mathrm{~mm}(150 \times 150 \mathrm{DPI})$ 
Fc and Fn for Douglas Fir processed with $1,5 \mathrm{~mm}$ of depth of cut

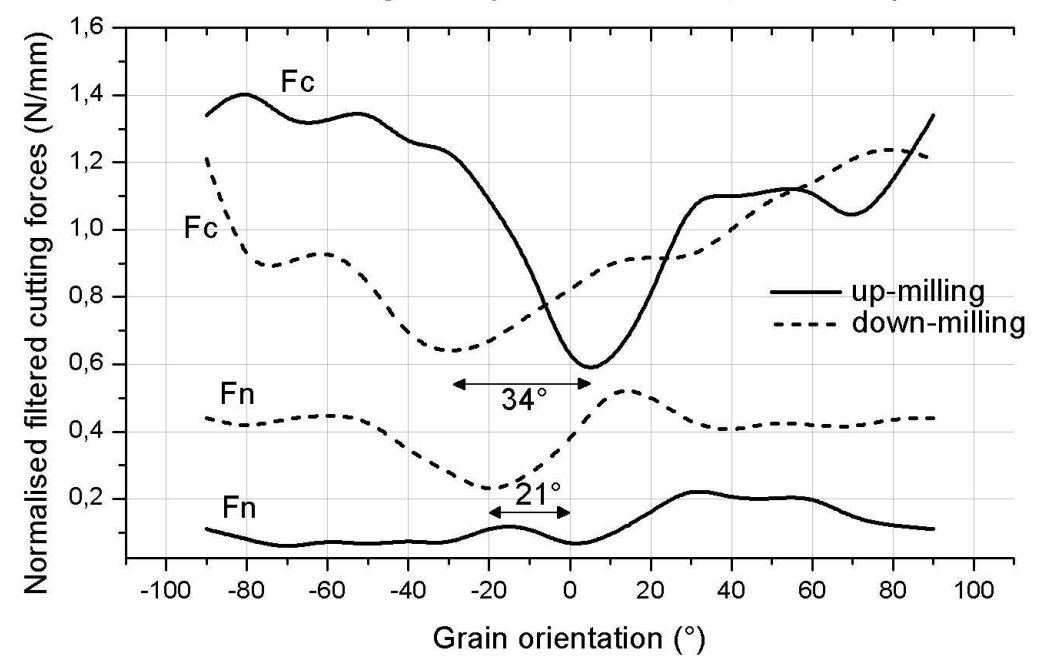

Figure 7: Principal (Fp) and normal forces (Fn) up and down milling Douglas Fir with 1,5 mm of depth of cut with different grain orientations. $287 \times 162 \mathrm{~mm}(150 \times 150 \mathrm{DPI})$ 
$\mathrm{R}$ force for Douglas Fir up and down-milling with 0,5 and $1,5 \mathrm{~mm}$ of depth of cut

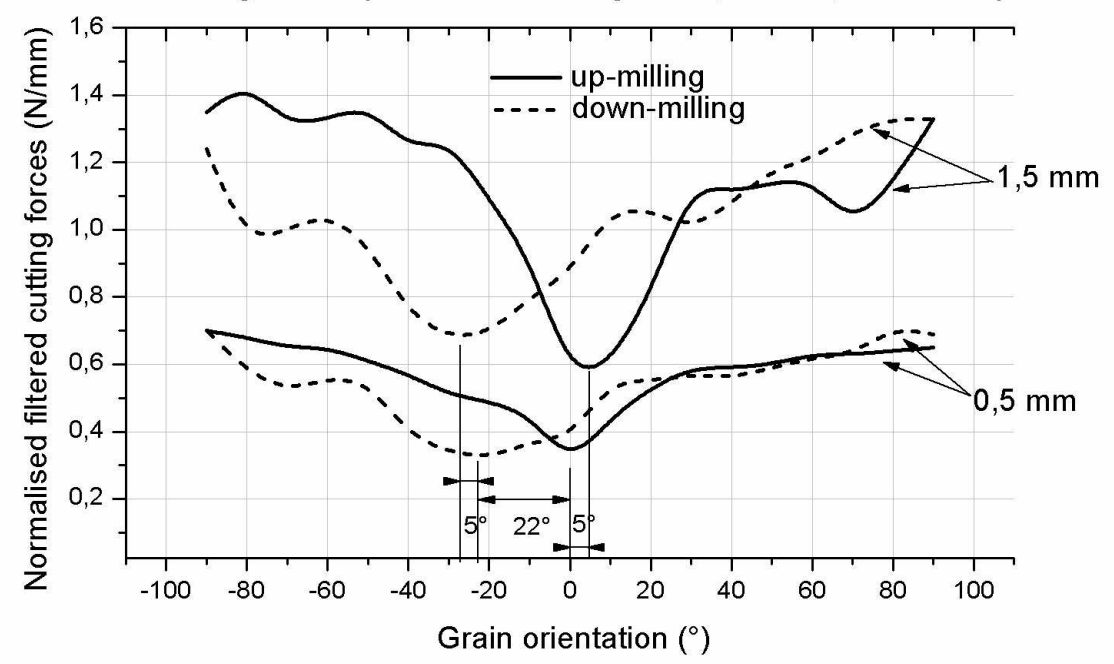

Figure 8: Resultant force magnitude when up- and down milling Douglas Fir with 0,5 and 1,5 mm of depth of cut. $287 \times 162 \mathrm{~mm}(150 \times 150 \mathrm{DPI})$ 
Resultant force angle vs. grain orientation

Figure 9: Resultant force angle (angle included between the normal force and the resultant force) when up- and down-milling Douglas Fir wit 0,5 and 1,5 mm of depth o cut. $227 \times 114 \mathrm{~mm}(150 \times 150 \mathrm{DPI})$ 
$191 \times 123 \mathrm{~mm}(300 \times 300 \mathrm{DPI})$ 
Coefficient of friction for Douglas Fir at 0,5 and $1,5 \mathrm{~mm}$ of dpth of cut

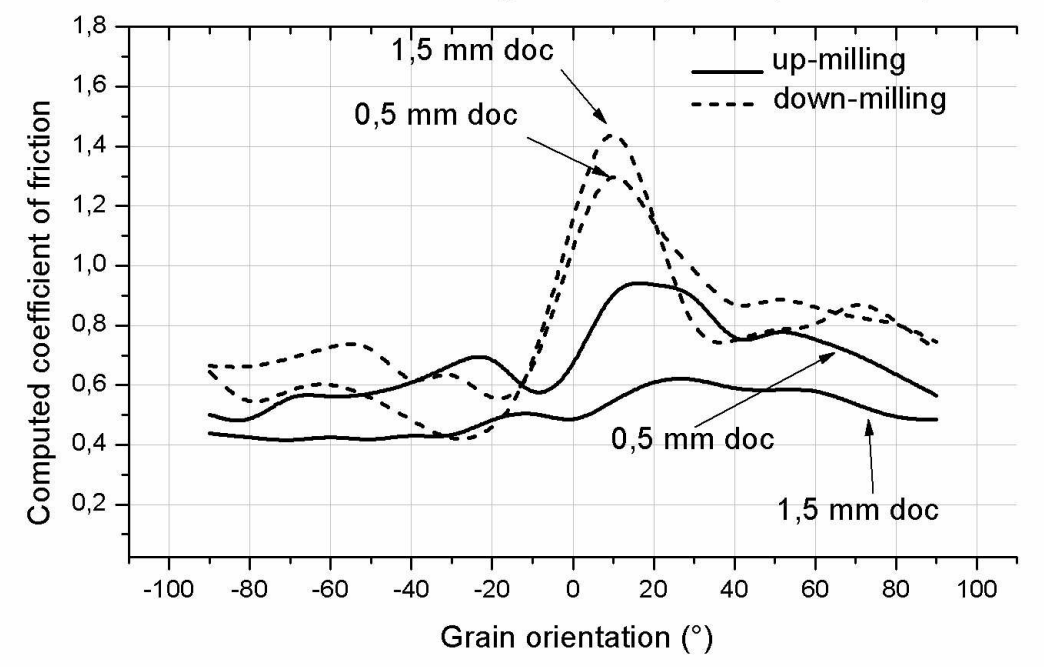

Figure 11: $\mathrm{S}$ and $\mathrm{N}$ ratio vs. grain orientation. $287 \times 162 \mathrm{~mm}(150 \times 150 \mathrm{DPI})$ 